\title{
eJEP)
}

\section{Leadership Can't Stand Alone: Why School Districts Need Policy to Increase Teacher Retention}

To cite this article: Sulit, A. (2020). Leadership can't stand alone: Why school districts need policy to increase teacher retention. eJournal of Education Policy, 21(2).

https://doi.org/10.37803/ejepF2008

\author{
Aimee Sulit, Ed.D. \\ Scottsdale Unified School District \\ 8500 East Jackrabbit Road \\ Scottsdale, Arizona 85250 \\ asulit@susd.org
}

\begin{abstract}
Current educational research identifies the significant relationship between principal leadership and teacher retention. In recent years, distributive leadership has been praised as a supportive leadership framework for school improvement. Given its success with transforming schools, distributive leadership has been suggested as a positive framework for increasing teacher retention. This research-based article concerns itself with qualities of distributive leadership that may support teacher retention. Results from the research call upon districts to develop policy in support of teacher retention. Specifically, this article provides current research from a recent study in Arizona that focused on the impact of distributive leadership with elementary and middle school teacher retention. This research was limited to a large school district in Arizona, though it revealed multiple areas where policy may support teacher retention. Ultimately, this article offers specific policy and practice considerations to mitigate teacher retention.
\end{abstract}

Keywords: distributive leadership, leadership, school policy, teacher attrition, teacher retention

\section{Introduction}

Education in Arizona may be caught in a rising tide of rough waters. In May 2018, thousands of educators from across the state flooded the Arizona State Capitol in a sea of red shirts. Since the initial Red for Ed movement, Arizona classrooms have continued to struggle in a myriad of ways. At the forefront of the storm, teacher retention remains a dominant concern. According to the Morrison Institute for Public Policy (2017), Arizona is losing more teachers from the profession each year than those annually graduating with bachelor of education degrees from its three major universities (Hunting, Reilly, Whitsett, Briggs, Garcia, \& Hart, 2017). The same 
report concluded that $42 \%$ of Arizona teachers hired in 2013 left the classroom after only three years (Hunting et al., 2017). These statistics are especially concerning when compared with national reports. According to the University Council for Educational Administration (2012), " $16 \%$ of the teacher workforce, or almost 500,000 teachers, left their school each year" (Castro, Quinn, Fuller, \& Barnes, 2018, p. 1). This statistic gains momentum when one considers that throughout the nation, teacher preparation programs are losing teachers. Between 2004 and 2012 alone, teacher preparation programs across the country experienced a $10 \%$ decline in program enrollment (Castro et al., 2018, p. 1). With fewer teachers seeking education as a viable profession, education is facing a sustainability issue that will leave our classrooms ill-equipped.

Education in Arizona is floating, but for how long? Additional measures are needed to support teachers with remaining in the classroom. The systemic issue of teacher retention calls for a multifaceted approach. While no one policy or initiative will likely heal the teaching crisis, research provides a glimpse into ways our school districts may positively impact teacher retention. One such area supported by research includes leadership.

Over the years, research continues to document the significant connection between teacher retention and administrative support (Darling-Hammond, 2003; Glaser, 2003; Hirsch, Emerick, Church \& Fuller, 2007; Loeb, Darling-Hammond, \& Luczak, 2005). In addition to administrator support, the literature highlights a positive relationship between principal leadership and teachers' organizational commitment (Hoy, Tarter, \& Bliss, 1990; Koh, Steers, \& Terborg, 1995; Nguni, Sleegers, \& Denessen, 2006). Organizational commitment remains a powerful indicator the research for teacher retention as it is frequently associated with teacher work performance and the overall quality of education (Dee, Henkin, \& Singleton, 2006; Tsui \& Cheng, 1999). Therefore, dismissing the impact of leadership in the equation of teacher retention would be premature.

The significant connection between leadership and teacher retention necessitates further investigation. While the construct of leadership is often met with mixed definitions and experiences, research once again provides relevant insights. Modern approaches recognize that a single individual cannot effectively lead in isolation (Burke, Fiore, \& Salas, 2003). Therefore, impactful school leadership must embrace a more inclusive framework to include multiple members. Distributive leadership has been labelled as the "hot item in the educational management literature" (Hulpia, Devos \& Van Keer, 2010, p. 46). Identified as an inclusive leadership framework, distributive leadership may offer insight into teacher retention by promoting teacher leadership.

\section{Statement of the Problem}

Ask an administrator in Arizona and he will tell you that teacher retention is a concern. According to survey results collected from the Morrison Institute for Public Policy (2017), 74\% of Arizona's school administrators are directly impacted by the teacher shortage (Hunting et al., 2017). The Arizona School Personnel Administrators Association (2019), reported that 1,547 classrooms in Arizona began the school year in 2018 with no teachers (Elizondo \& Wing, 2019). In the same year, 663 teachers quit within the first month of school. The ASPAA (2019) further 
concluded that $21 \%$ of Arizona's teacher vacancies were unresolved well into the beginning of the school year with unqualified "teachers" filling the positions (Elizondo \& Wing, 2019).

Nationally, the prognosis for teacher retention is startling. Projections estimate that a meager 200,000 teachers will be available for hire by 2025, highlighting a gap of more than 100,000 teachers each year (Sutcher et al., 2016, p. 3). With significant reductions in teachers available, our students are at risk. This risk is even greater among our struggling schools, where the cycle of poverty negatively impacts teacher retention. This "vicious cycle" has been identified in the research as creating "hard-to-staff-schools" (Sutcher et al., 2016, p. 5). According to the research, these struggling schools "typically end up with a disproportionate number of relatively inexperienced teachers, who typically leave at much higher rates than other teachers" (Sutcher et al., 2016, p. 5).

Increasing teacher retention will require investment from coordinated partnerships within the educational system. According to the National Commission on Teaching and America's Future (2007), investing in teacher retention has the potential to "reduce teacher turnover, and thus reduce the costs associated with teacher turnover" (as cited in Barnes et al., 2007, p. 5). Admittedly, the price tag associated with teacher turnover is substantial. The National Commission on Teaching and America's Future estimate that schools spend roughly $\$ 17,872$ to fill each teacher vacancy, including costs of recruitment, interviewing, and training teachers (Karp, 2014). In order to turn the tide regarding teacher retention, careful attention must be given to key aspects within the research that impact formidable school policy and practice.

Discussions surrounding policy must include advocating for leadership practices that support our teachers with remaining in the classroom. Research shows that leadership significantly impacts teacher retention (Borman \& Dowling, 2006; Brill \& McCartney, 2008). Specifically, distributive leadership may offer tremendous insight with regard to teacher retention. While promoted as an effective leadership framework (Hallinger and Heck, 2009; Ross et al., 2016), the research on distributive leadership is underdeveloped (Gronn, 2010). Additional research is necessary to identify qualities of distributive leadership that may positively increase teacher retention.

\section{Discussion of Literature}

\section{Distributive Leadership}

Amongst the backdrop of multiple leadership models, distributive leadership has gained recognition in the education world as the "preferred leadership model" for the 21 st century (Bush, 2013, p. 543). Distributive leadership is known as a significantly impactful framework for initiating and sustaining school improvement (Hallinger and Heck, 2009). Day et al. (2009) conducted research highlighting distributive leadership's positive impact on student academic outcomes. Specifically, Day et al. (2009) found that "substantial leadership distribution was very important to a school's success in improving pupil outcomes" (p. 17). Ritchie and Woods (2007) connected distributive leadership's success with its ability to promote meaningful configurations 
of leadership amongst capable teachers and staff. Accordingly, distributive leadership achieves positive outcomes by promoting collective interest and responsibility at the school level (Ritchie \& Woods, 2007).

This study utilized Spillane's (2006) seminal framework of distributive leadership, emphasizing the relationship between school leaders, followers, and situations. This distributive leadership framework encourages teachers to work collaboratively with site administration utilizing formal and informal roles to impact school improvement (DeFlaminis et al., 2016; Spillane, 2006). Thus, distributive leadership is viewed as "descriptive rather than prescriptive" (DeFlaminis et al., 2016, p. 9). As such, distributive leadership is a "framework for understanding leadership, which emphasizes the embedded, shared, and practice-oriented nature of organizational leadership" (DeFlaminis et al., 2016, p. xvii).

Distributive leadership provides deliberate pathways for administrators to share and distribute leadership within a school (Harris, 2011). Intentional dispersion of leadership responsibilities has been linked with improved organizational outcomes and increasing teacher satisfaction (Ross, Lutfi, \& Hope, 2016, p. 162). As a significant influencer of school improvement, distributive leadership promotes a "multidirectional flow of influence that entwines the principal, teachers, counselors, and other organization members" (Ross et al., 2016, p. 159). Over time, schools develop formal and informal networks of qualified teacher leaders. Thus, utilizing the expertise of multiple teacher leaders within a school, the entire organization is able to progress (Tahir et al, 2016).

Findings in the literature identify the potential of the distributive leadership framework to offer untapped potential in the realm of teacher retention (Spillane, 2006, p. 30). Research shows that "leadership may support efforts to recruit, retain, and develop the best teachers and mitigate teacher turnover" (DeFlaminis, Abdul-Jabbar \& Yoak, 2016, p. 84). As a recognized framework for school improvement, this study seeks to identify the qualities of distributive leadership that may positively impact teacher retention. In so doing, this study identifies future opportunities for policy development.

\section{Teacher Retention}

Teacher retention is significantly correlated with administrative leadership in the research (Borman \& Dowling, 2006; Brill \& McCartney, 2008; Hall et al.,1992; Ingersoll, 2001; Ingersoll \& Smith, 2003; Johnson \& Birkeland, 2003; Kersaint et al., 2007; Kukla-Acevedo, 2009; Stockard \& Lehman, 2004; Swars et al., 2009; Wynn et al., 2007). Ladd (2009) identified teacher perception of school leadership as the most significant working condition impacting teacher retention. Ulrick (2016) affirmed the significance of teacher perceptions of school leadership, asserting that "[ $\mathrm{t}]$ eacher perception of leadership is a well-established predictor of attitudes associated with teacher decisions to stay or leave” (p. 435). In addition, research shows that teachers experience greater levels of organizational commitment and empowerment in their positions when administrators facilitate opportunities to share in decision-making, support professional development, and promote community relations (Bryk, Sebring, Allensworth, Luppescu, \& Easton, 2010; Urick, 2016). 
While teachers' perceptions of leadership greatly impact teacher retention, ineffective or negative leadership poses a significant threat to teachers' decisions to remain in the classroom. Inadequate administrative support has been identified as one of the most detrimental factors associated with teacher attrition (Prather-Jones, 2011; Schlichte, Yssel, \& Merbler, 2005; Struyven \& Vanthournout, 2014). Furthermore, research shows that teacher retention is negatively influenced by teachers' perceptions of reduced autonomy, increased micromanagement, and decreased decision-making with impacting school policy (Struyven \& Vanthournout, 2014). Collectively, findings from the literature and data presented within this study identify implications for policy development that recognize teachers as leaders.

\section{Policy and Practice}

Federal and state initiatives provide financial support to address teacher retention. This funding provides an initial step with supporting teacher candidates and novice teachers interested in the profession. Federal funding is granted through the College Cost Reduction and Access Act of 2007. This legislation funds the Teacher Education Assistance for College and Higher Education (TEACH) Grant Program. TEACH provides up to $\$ 4,000$ per year to students who plan to teach in a K-12 school serving students from low-income families. The TEACH Grant requires applicants to pursue high-need areas, such as: bilingual education, foreign language, mathematics, reading specialist, mathematics and science. Additional areas may be approved based upon additional listings identified at the state or local level. TEACH Grant funds are approved for teachers serving in high-need schools for a minimum of four years.

At the state level, Arizona offers support for men and women interested in pursuing education via their Arizona Teachers Academy. The Arizona Teachers Academy (ATA) scholarship provides financial assistance in the form of tuition and fees for those students enrolled in a state university or community college teacher preparation program. The scholarship is applicable after a student has accepted all other non-loan aid. Students receiving the Arizona Teachers Academy (ATA) scholarship must commit to one year of teaching in an Arizona public school for each year funds were received.

Initiatives at the federal and state level provide introductory opportunities to entice new teachers. These measures provide viable financial support in the early stages of a teacher's career. Additional financial opportunities are available for teachers in the form of scholarships or grants. For example, the Armed Forces Communications and Electronics Association (AFCEA) offers scholarships for teacher candidates interested in pursuing science, technology, engineering or math within our K-12 schools. Several other financial opportunities exist, but none provide continued support in the classroom. Teachers currently in the field may pursue additional grants for their classroom. However, those new to the profession may not be aware of additional opportunities.

Outside of federal and state grants, there are few policies in place to support teacher retention. The Arizona School Boards Association (ASBA) provides guidance for Arizona school districts seeking to adopt policy. While ASBA provides a wealth of information to surrounding districts 
on a multitude of areas, it lacks guidance in the area of teacher retention. ASBA lends policy directives to districts in the form of policies directing employment practices for hiring and firing teachers, teacher professionalism, teacher evaluation, and curriculum adoption. Yet, these policies do not explicitly support our teachers with remaining in the classroom. Many Arizona districts advertise policy seeking well-trained and knowledgeable teachers, yet do not provide assurances for how new teachers or those early in their career will be cared for once they are hired.

While states such as Arizona are lacking policy to support teacher retention, others are making notable efforts. Connecticut's Beginning Educator Support and Training (BEST) program is funded by the Education Enhancement Act, BEST provides between two and three years of guaranteed support for beginning teachers. Under BEST, Connecticut requires and finances mentoring of novice teachers for at least one year and requires districts to provide professional development. First-year teachers work with teacher mentors to develop basic teaching abilities such as classroom management. Mentors utilize a state-developed assessment to ensure new teachers' success (Curran \& Goldrick, 2002). During the second year, teachers learn and develop specific teaching strategies. According to the literature, "Connecticut's sustained effort is the most ambitious undertaking in any state to use high-leverage, performance-based teaching assessments as a tool to transform professional practice" (Barnett, Hopkins-Thompson, and Hoke 2002, 14).

Without policy lending guidance for administrators and teachers, districts may be left scrambling to locate resources and support. Additional discrepancies may surface as principals with varied levels of training provide incongruous opportunities. Simply put, policy is needed to provide a consistent, base-level of support for our teachers to remain in the classroom.

\section{Research Methodology}

This article examined the qualities of distributive leadership that may positively influence elementary and middle school teacher retention. Moustakas' (1994) Transcendental Phenomenology Framework provided the theoretical framework and guiding methodology for this qualitative research. As a research method, phenomenology provided data from in-depth interviews to fully capture participants' lived experiences (Van Manen, 2014). In so doing, this qualitative study was informed by three guiding research questions:

1. What qualities of distributive leadership may improve teacher retention?

2. How do elementary and middle school teachers experience distributed leadership?

3. Do elementary and middle school teachers' current experiences with distributive leadership influence their desire to remain in the classroom?

\section{Data Collection: In-Depth Interview}

Following a principal focus group, elementary and middle school teachers were selected to participate in in-depth teacher interviews. During the teacher in-depth interviews, participants 
were asked open-ended questions to ensure freedom with responding. Elementary and middle school teachers responded to eight guiding interview questions.

1. How would you describe the leadership at your current school?

2. Describe how teachers participate in leadership at your current school.

3. How have you personally experienced leadership at your current school? How have these experiences affected you? What thoughts stand out for you? What feelings stand out for you?

4. Describe your current principal's leadership style.

5. What impact does leadership have in your decision to remain in the teaching profession?

6. What other factors support your decision to remain in the classroom?

7. If you were a principal, what changes would you make to support teacher retention?

8. Having thought about leadership, what else would you like to share?

\section{Study Sample and Target Population}

This qualitative study reflects the experiences of 7 elementary and 6 middle school teachers from two schools in the suburbs of Phoenix, Arizona. Criterion sampling was used to select teacher participants. Criterion sampling ensured that "all individuals studied represent people who have experience the phenomenon" (Creswell \& Poth, 2018, p. 157). Accordingly, participants were required to serve within the identified district as currently employed teachers at one of two sites (one elementary and one middle) identified by an initial principal focus group.

\section{Analysis}

Moustakas' (1994) guidelines for phenomenological analysis provided the structure for analyzing the teacher interview data. Prior to instrumentation, the researcher developed a list of significant statements to guide the initial process of coding. Throughout the process, significant statements were modified to include the most accurate representations. Horizontalization of the data was used to "develop a list of nonrepetitive, nonoverlapping statements" or codes (Creswell $\&$ Poth, 2018, p. 201). The researcher highlighted significant quotes and identified relating categories. Significant statements were grouped into related categories or "broader units of information" (Creswell \& Poth, 2018, p. 201). Themes were developed to describe the experience of distributed leadership and remove repetition (Creswell \& Poth, 2018, p. 201). Textural descriptions of the participants' experiences with distributive leadership were documented with quoted examples. In addition, structural descriptions were created to identify teachers' experiences with distributed leadership that signify the "setting and context in which the phenomenon was experienced" (p. 201). Finally, the researcher produced a composite description or essence that included meaningful examples from the textural and structural descriptions of the elementary and middle school teachers' experiences.

\section{Validity and Reliability}

Multiple validation strategies were used to address the researcher's lens, participant's lens, and reader's lens (Creswell \& Poth, 2018, p. 261). Multiple data sources from teacher interviews were reviewed to address the researcher's lens and clarify. Corroborating interview data from numerous sources ensured that teacher experiences were shared amongst multiple participants. 
Prior to conducting teacher interviews, the researcher identified personal reflexivity. Clarifying reflexivity allowed the researcher to separate preconceived values and beliefs from the data. Following each in-depth interview, participants were given the opportunity to provide feedback on initial codes from the researcher's codebook. This provided the opportunity to validate the participant's lens as teachers were able to "judge the accuracy and credibility of the account" (Creswell \& Poth, 2018, p. 261). The participant lens was further addressed as teachers were given the opportunity to supplement additional information during the in-depth interviews. Finally, the researcher validated the reader's lens by including colleagues' peer review of the data collection process.

Reliability within the data was achieved by including multiple procedures to ensure intercoder agreement (Creswell \& Poth, 2018, p. 265). The researcher developed a preliminary code list and codebook to assist initial data collection. The codebook was reviewed with multiple teacher participants and colleagues to ensure reliability within the data. The researcher's codebook sustained numerous revisions until a conclusive set of codes were achieved.

\section{Findings}

\section{(RQ1) What qualities of distributive leadership may improve teacher retention?}

Six themes were identified as qualities that may improve teacher retention: Administrative Support, Extra Work/Teacher Responsibilities, Culture/Climate, Making a Difference/Joy in the Classroom, Leadership: Tough Stuff, and Balance: Work/Family (see Table 1).

Administrative support. Three elementary and three middle school teachers valued the importance of working for a supportive principal. The elementary teacher participants described the significance of their principal in maintaining open communication. In addition, elementary teachers expressed feeling supported by their administration with school initiatives.

The literature addresses the significance that Administrative Support lends to the discussion about teacher retention. In fact, Boyd et al. (2011) identified "teachers' perceptions of the school administration" as the most significant factor related to teacher retention (p. 321). Similarly, Urick (2016) identified school leadership as a significant predictor of teacher retention.

Extra Work/Teacher Responsibilities. Three elementary and five middle school teachers expressed concern regarding the Extra Work/Teacher Responsibilities associated with distributive leadership. Elementary and middle school teachers described Extra Work/ Teacher Responsibilities as an over-filling of their "plates" in the classroom. Both teacher groups shared experiences that included additional meetings before, during, and after school. Elementary and middle school teachers perceived Extra Work/ Teacher Responsibilities as being stressful.

Extra Work/Teacher Responsibilities is not typically associated with improving teacher retention. In fact, research correlates additional work and responsibilities with teacher attrition (Brill \& McCartney, 2008; Johnson \& Birkeland, 2003; Kersaint et al., 2007). Hughes (2012) found that limiting teacher work may positively impact teacher retention. With the experience of distributive leadership being highly connected with Extra Work/Teacher Responsibilities, 
administrators seeking to use this framework may need to research healthy ways to support teachers with balancing the additional leadership responsibilities.

Culture/Climate. Three elementary and two middle school teachers shared positive experiences with Culture/Climate. Even so, elementary and middle school teachers experienced Culture/Climate differently. Elementary teachers focused on the significance of relationships at their school and feeling connected with their fellow teachers. Additionally, elementary teachers appreciated being able to make key decisions at their school. However, middle school teachers described culture and climate as directly reflecting their principal's ability to set a positive tone. Middle school participants reinforced the importance of having an administrator check-in with teachers to establish a positive rapport.

Culture/Climate is positively associated with teacher retention. Wynn et al. (2007) observed that school climate has a positive impact on teacher retention. Furthermore, a positive work environment has also been associated with organizational commitment (Dorman, 2003; Loeb et al., 2005; Skaalvik and Skaalvik, 2010). In the distributive leadership environment, teacher relationships, opportunities for decision-making, and support from colleagues are typical. This may increase teachers' organizational commitment and encourage them to remain in the classroom.

Making a Difference/Joy in the Classroom. Five elementary and three middle school teachers shared their positive experiences with making a difference in their students' lives or experiencing joy in the classroom environment. Both teacher groups expressed an overall excitement to work with children. Elementary and middle school teachers expressed feeling "passion" or "joy" working with their students.

Distributive leadership is positively and significantly linked with job satisfaction (Torres (2017). In addition, teachers may be more likely to leave the classroom when presented with a mismatch between expectations and reality (Hughes, 2012). Distributive leadership has the potential to positively respond to teachers' expectations since teachers are directly connected to school improvement. Furthermore, distributive leadership may foster teacher retention by providing additional opportunities for teachers to directly making a difference in the lives of their students.

Balance: Work/Family. Three elementary and two middle school teachers discussed Balance: Work/Family as a quality of distributive leadership that may impact teacher retention. Both teacher groups discussed the importance of having regular breaks in the summer and throughout the year to spend time with family. In addition, elementary and middle school participant groups discussed how having flexibility with their work schedules allowed them to schedule doctor and other appointments.

Personal reasons and marriage may negatively impact teacher retention. Married teachers leave the classroom 1.40 times greater than those who are not married (Borman \& Dowling, 2008, p. 385). Distributive leadership has the potential to balance teacher responsibilities by sharing the work amongst capable teacher leaders, thus improving teacher retention. 
Table 1 (Sulit, 2020, p. 184)

RQ1 Overall Themes and Imaginative Variation

Elementary Teachers

RQ1 Overall Themes

- Parent/ Community Support (6)

- Making a Difference/Joy in the Classroom (5)

- Teacher Support (5)

- Administrative Support (4)

- Culture/Climate (4)

- Extra work/Teacher Responsibilities (4)

- Instructional Shifts/Changes at the School

(4)

- Balance: Work/Family (3)

- Salary (3)

- Decision-Making (2)

- Professional Development/Mentoring (2)

- Previous Superintendent (2)

- Leadership: Tough Stuff(2)

Imaginative Variation

- Salary (3)

- Previous Superintendent (2)

- Leadership: Tough Stuff (2)

- Leadership Turnover (1)

- RED 4 Ed (1)

- Generational Changes (1)

- Previous Ambitions (1)
Middle School Teachers

RQ1 Overall Themes

- Administrative Support (6)

- Extra Work/Teacher Responsibilities (6)

- Culture/Climate (3)

- Making a Difference/Joy in the Classroom (3)

- Leadership: Tough Stuff(3)

- Valuing/Affirming Teachers (3)

- Balance: Work/Family (2)

Note. Common themes between groups are italicized.

(RQ2) How do elementary and middle school teachers experience distributed leadership? Elementary and middle school teachers shared four significant themes to describe their experience with distributive leadership: Administrative Support, Teacher Leadership: Formal, Decision-Making, and Teacher Leadership: Informal (see Table 2).

Administrative support. Six elementary and four middle school teachers experienced Administrative Support at their respective schools. Elementary and middle school teachers expressed appreciation for receiving tangible resources and materials to enhance student 
learning. In addition, both groups described their appreciation of administration providing relevant professional development to nurture their classroom instruction.

Administrative Support is documented in the literature as organizational commitment increases among teachers who feel supported by their principal leadership (Hulpia et al., 2012).

Thibodeaux et al. (2015) identified a significant relationship between principal leadership style and teacher moral, teacher satisfaction, and teacher attrition. Since the distributive leadership framework often lends itself to working cooperatively, it is not surprising that Administrative Support was identified as a common experience between Elementary and middle school teachers.

Teacher leadership: Formal. Seven elementary and six middle school teachers experienced formal leadership roles at their respective schools. Both participant groups described how Teacher Instructional Leaders (TILs) provided support for teachers and facilitated schoolwide initiatives. Additionally, elementary and middle school teachers described how their respective site Leadership Teams supported school operations. Moreover, both groups described how teachers absorbed leadership roles with facilitating student clubs.

Research indicates that "the formal distribution of supportive leadership among the leadership team [has] a positive significant impact on teachers' commitment to the school." (Hulpia et al., 2009b, p. 46). The distributive leadership framework typically includes formalized leadership roles to support school improvement.

Decision-Making. Two elementary and three middle school teachers shared their overall positive experiences with decision-making. While both participant groups valued their ability to make impactful decisions, elementary teachers discussed experiences decision-making with several teachers. Alternately, middle school teachers described how they influence school improvement by making impactful decisions, such as researching instructional strategies or innovative technologies.

Research shows that decision-making is a predictor of teacher retention (Borman \& Dowling, 2008; Boyd et al., 2011; Brown \& Wynn, 2009; Horng, 2009; Weiss, 1999). Hulpia et al. (2009b) contributed to the literature by finding that "participation in decision-making increased people's commitment to the organization" (p. 46). The distributive leadership framework provides teachers with frequent opportunities to lead impactful change; therefore, potentially encouraging teachers to remain at their schools.

Teacher leadership: Informal. Two elementary and three middle school teachers described their experiences with informal leadership. Both participant groups discussed how teacher leadership naturally surfaces at their respective schools. Both teacher groups perceived their administration genuinely supported their informal leadership. Elementary and middle school teachers expressed feeling comfortable with assuming leadership and taking risks.

According to the literature, leadership encompasses three components related to teacher retention: modelling of effective teaching, coaching and mentoring, and creation of developmental tasks to improve learning and teaching (Harris \& Muijs, 2003, p. 40). 
Distributive leadership is frequently associated with providing formal and informal leadership opportunities that allow teachers to impact their school in meaningful ways.

Table 2 (Sulit, 2020, p. 233)

$R Q 2$ Overall Themes and Imaginative Variation

Elementary Teachers $\quad$ Middle School Teachers

RQ2 Overall Themes

- Administrative Support (10)

- Teacher Leadership: Formal (7)

- Shared Leadership (5)

- Strong Leadership (3)

- Decision-Making (3)

- Teacher Support (3)

- Teacher Leadership: Informal (3)

- Consistent Expectations (2)

- Leadership: Tough Stuff (2)

- Culture/Climate (2)

- Student-Centered Leadership (2)

- Extra work/Teacher Responsibilities (2)

- Rebuild (2)

Imaginative Variation

- Rebuild (2)

- Administrator Relationship (1)

- RED 4 Ed (1)

\section{RQ2 Overall Themes}

- Administrative Support (6)

- Teacher Leadership: Formal Roles (6)

- Inclusive/Multidirectional Communication (5)

- Administrator Expectations (4)

- Decision-Making (4)

- Direct Communication/Not Warm and Fuzzy (4)

- Visionary Leadership (4)

- Decisive Leadership/Action- Oriented (3)

- Leadership Turnover (3)

- Teacher Leadership: Informal (3)

- Balance: Teaching Role (2)

- Micromanagement (2)

Imaginative Variation

- Leadership Turnover (3)

- Previous Leadership Experience (1)

- First Year of Teaching (1)

- Student Teaching Experience (1)

- Previous Experience at Previous School (1)

- Previous Work Relationship (1)

Note. Common themes between groups are italicized.

(RQ3) Do elementary and middle school teachers' current experiences with distributive leadership influence their desire to remain in the classroom?

Teacher participants described their experiences with distributive leadership as having either a Positive Impact, Negative Impact, or No Impact (see Table 3).

DL/Positive Impact. Four elementary and three middle school teachers described distributive leadership as positively impacting their decision to remain in the classroom. Despite these teachers' overall favorable reactions, their responses may be linked with the fear of experiencing 
micromanagement at another campus. Elementary and middle school teacher participants discussed micromanagement negatively.

DL/Negative Impact. One elementary and one middle school teacher described distributive leadership as negatively impacting their decision to remain in the classroom. The elementary teacher participant described the extra work associated with distributive leadership as filling her "plate" beyond the teaching role. Alternately, the middle school teacher participant experienced distributive leadership as negatively impacting his campus, identifying a mismatch between test scores over the social and emotional aspects of children.

DL/No Impact. Two elementary and two middle school participants described distributive leadership as not having an impact on their decision to remain in the teaching profession. Due to the ability to transfer schools, one elementary and one middle school teacher discussed their indifference with distributive leadership.

RQ3 demonstrates the complex nature of distributive leadership as it relates to teacher retention. This study identified a nearly even split between DL/ Positive Impact and DL/Negative Impact and DL/ No Impact. Data collected from this study is consistent with the literature surrounding distributive leadership and teacher retention. According to the literature, distributive leadership is difficult to define (Bennett et al., 2003; Bolden, 2011; Hartley, 2007; Timperley, 2005). Lacking a consistent definition of distributive leadership, it is difficult to determine its impact on teacher retention. Additionally, extra work commonly associated distributive leadership is commonly perceived negatively by teachers, resulting in a negative relationship with teacher retention (Lumby, 2018). Furthermore, the literature reflects a negative association with distributive leadership overemphasizing data from student test scores to measure its effectiveness (Woods \& Woods, 2013). 
Table 3 (Sulit, 2020, p. 246)

RQ3 Overall Themes

Elementary Teachers

IQ5: What impact does leadership have in your decision to remain in the teaching profession?

- DL/Positive Impact

- Appreciates positive leadership/ fear of micromanagement at another school

- Hopes to impact newer teachers to assume leadership roles

- Administration supports culture and climate of the school

- Appreciates being able to take-on leadership roles

- DL/Negative Impact

- Would consider leaving due to extra work associated with leadership; may consider staying due to strong teacher support

- DL/No Impact

- Not sure/ would be willing to transfer schools or stay regardless of leadership

- Not returning due to personal reasons/ not impacted by leadership
Middle School Teachers

IQ5: What impact does leadership have in your decision to remain in the teaching profession?

- DL/Positive Impact

- Appreciates positive leadership/ fear of micromanagement at another school

- Positive experiences offset her previous beliefs from student teaching

- Feels supported by administration

- DL/Negative Impact

- Would leave if academic pressures increase

- DL/No Impact

- Would transfer to another school

- Adjusted his teaching environment

\section{Conclusions}

Teacher retention is weighty issue. In August 2018, 1,547 of Arizona classrooms had no teachers to welcome students on the first day of school (Elizondo \& Wing, 2019). At a time where the education profession is searching for relief, leadership has been promoted in the literature as positively impacting teacher retention (Borman \& Dowling, 2006; Brill \& McCartney, 2008). Specifically, distributive leadership is a recognized in the literature as a significant framework related to school improvement (Hallinger and Heck, 2009). Previous research suggests that distributive leadership may support teacher retention (DeFlaminis, AbdulJabbar \& Yoak, 2016).

This article sought to identify the qualities of distributive leadership that may positively impact teacher retention. Participant data yielded mixed results regarding the effectiveness of distributive leadership in response to three research questions. RQ1 addressed the qualities of distributive leadership that may improve teacher retention. Six themes emerged as qualities that 
may improve teacher retention: Making a Difference/Joy in the Classroom, Administrative Support, Culture/Climate, Extra Work/Teacher Responsibilities, and Balance: Work/Family. In addressing RQ1, school leaders may enact policy to reflect these positive themes to support our teachers with remaining in the classroom.

RQ2 addressed elementary and middle school teachers' experiences with distributive leadership. Four themes emerged that described the participants' experiences with distributive leadership: Administrative Support, Teacher Leadership: Formal, Decision-Making, and Teacher Leadership: Informal. As policymakers consider avenues for policy development, they may reflect upon this data by including teachers' voice, input, decision-making and leadership.

RQ3 addressed whether or not teachers' current experiences with distributive leadership influenced their desire to remain in the classroom. Three themes to surfaced from the teacher interviews. Teacher participants experienced distributive leadership as having a Positive Impact, Negative Impact, or No Impact. Roughly half of the teacher participants viewed distributive leadership positively and felt that it would support their decision to remain in the classroom. However, the other half viewed distributive leadership negatively or did not feel that it impacted their decision to remain in the classroom.

\section{Implications and Recommendations}

Data produced from this study demonstrates that teachers experience a variety of needs with regard to teacher retention that offer direct implications for policy makers.

- Data collected from this study suggest that teachers experience distributive leadership differently. Therefore, attempts to support teacher retention with a distributive leadership framework will require administrators to determine the varied needs on their campuses. Administrators must be prepared to develop policy that is flexible in providing support for teachers while providing a consistent base of experiences.

- Teacher experiences with distributive leadership suggests the need for educators to have input in making decisions that directly impact their work environment. Policy makers may recognize this need by including teachers in leadership roles to suggest and collaborate on policy initiatives that directly impact teacher retention. Specifically, this study suggests the need for policy to address the qualities of distributive leadership that promote teacher retention.

- Administrators and educational practitioners may conduct an internal investigation of teachers' attitudes and perceptions regarding the leadership at each of their schools and district office. Utilizing this data may provide an essential first step in developing meaningful policy that supports teacher leadership and teacher retention.

- Educational leaders may conduct an internal analysis regarding ways teachers participate in leadership at each of their schools. Specifically, district leaders may evaluate schools' procedures for selecting, sharing, and recognizing teacher leadership. Moreover, schools 
may address how teachers perceive these procedures at each level. Utilizing this data may support initial plans for policy development aimed at increasing teacher retention.

- District leaders may create a committee (including district leaders and teachers) to address positive solutions for minimizing the extra work commonly associated with distributive leadership. Given the negative association between teacher retention and extra work, district leaders will need to investigate this thoroughly prior to enacting policy.

- District leaders may conduct an internal audit to further identify the impact of principal turnover and teacher attrition. Specifically, district leaders will need to identify how administrator turnover impacts teachers' success in the classroom. Policy may be created from this research to minimize the impact of leadership changes.

- K-12 institutions may conduct an internal investigation of district-sponsored teacher preparation programs to support readiness of teacher candidates. Specifically, districts may identify ways that experienced, mentor teachers may serve in a leadership capacity to support teacher retention. Policy may be created from this investigation to support a uniform level of teacher preparation.

- K-12 institutions may partner with local universities to identify initiatives that may support teacher retention. Specifically, districts and universities may identify ways of supporting teachers directly in the classroom over a period of multiple years to ensure teachers' ongoing needs are met. Districts may formally address these initiatives with concrete policy to ensure a consistent base of support. 


\section{References}

Barnes, G., Crowe, E., \& Schaefer, B. (2007). The cost of teacher turnover in five school districts: A pilot study. National Commission for Teaching America's Future. Washington D.C. Retrieved from https://pdfs.semanticscholar.org/b4ab/6eaa2ac83f4721044e5de193e3e2dec07ac0.pdf

Barnett, B., Hopkins-Thompson, P., \& Hoke, M. (2002). Assessing and supporting new teachers. Chapel Hill, NC: Southeast Center for Teaching Quality. Retrieved from https://www.cga.ct.gov/2007/pridata/studies/best_final_report.htm

Bennett, N., Wise, C., Woods, P., \& Harvey, J. (2003). Distributed leadership: Full report (Nottingham, NCSL). Retrieved from http://www.ncsl.org.uk/media/3C4/A2/distributedleadership-literature-review.pdf

Bolden R (2011) Distributed leadership in organizations: A review of theory and research. International Journal of Management Reviews, 13, 251-269.

Borman, G. D., \& Dowling, N. M. (2006). Teacher attrition and retention: A meta-analytic and narrative review of the research. Review of Educational Research, 28, 25-48. doi:10.3102/0034654308321455

Borman, G. D. \& N. Dowling, N. M. (2008, September). Teacher attrition and retention: A metaanalytic and narrative review of the research. Review of Educational Research, 78(3), $367-409$.

Boyd, D., Grossman, P., Ing, M., Lankford, H., Loeb, S., \& Wyckoff, J. (2011). The influence of school administrators on teacher retention decisions. American Educational Research Journal, 48(2), pp. 303-333.

Brill, S., \& McCartney, A. (2008). Stopping the revolving door: Increasing teacher retention. Politics \& Policy, 36, 750-774. doi:10.1111/j.1747-1346.2008.00133.x

Brown, K. M., \& Wynn, R.S. (2009). Finding, supporting, and keeping: the role of the principal in teacher retention issues. Leadership and Policy in Schools, 8(1), 37-63.

Bryk, A., Sebring, P., Allensworth, E., Luppescu, S., \& Easton, J. (2010). Organizing schools for improvement: Lessons from Chicago. Chicago, IL: The University of Chicago Press.

Burke, C. S., Fiore, S. M., \& Salas, E. (2003). The role of shared cognition in enabling shared leadership and team adaptability. In C. L. Pearce, \& J. A. Conger (Eds.), Shared leadership: Reframing the hows and whys of leadership (pp. 103-122). Thousand Oaks, CA: SAGE.

Bush, T. (2013). Distributed leadership: The model of choice in the 21st century. Educational Management Administration \& Leadership, 41(5) 543-544. 
Castro, A., Quinn, D. J., Fuller, E., \& Barnes, M. (January 2018). Policy brief 2018-1: Addressing the importance and scale of the U.S. teacher shortage. University Council for Educational Administration. Retrieved from http://www.ucea.org/wpcontent/uploads/2018/01/Addressing-the-Importance-and-Scale-of-the-US-TeacherShortage.pdf

Creswell, J. W., \& Poth, C. N. (2018). Qualitative inquiry \& research design: Choosing among the five approaches (4th ed.). Thousand Oaks, CA: SAGE.

Darling-Hammond, L. (2003). Keeping good teachers: Why it matters, what leaders can do. Educational Leadership, 86, 42-51.

Day, C., Sammons, P., Hopkins D., Harris, A., Leithwood, K., Gu, Q., Kingston, A. (2009). The impact of school leadership on pupil outcomes. London, UK: Final Report DCSF.

Dee, J. R., Henkin, A. B., \& Singleton, C. A. (2006). Organizational commitment of teachers in urban schools: Examining the effects of team structures. Urban Education, 41, 603-627.

DeFlaminis, J. A., Abdul-Jabbar, M., \& Yoak, E. (2016). Distributed leadership in schools: A practical guide for learning and improvement. New York, NY: Routledge.

Dorman, J. (2003). Relationship between school and classroom environment and teacher burnout: A LISREL analysis. Social Psychology of Education, 6(2), 107-127.

Elizondo, L., Wing, J. (August 2019). Severe teacher shortage in Arizona continues. Arizona School Personnel Administrators Association. Retrieved from https://drive.google.com/file/d/0BwNzjv2A0DdcMjd1b2JsTlFDNVAwY0poeFBiaFEzL WRTcGtJ/view?fbclid=IwAR00kZxcJ7hScSxf5J87FP4WvJmYS91mqFaKVDHOfO8vF 7BV6NLOuAOmNJI

Glaser, W. (2003). Four ways to sustain all teachers. In M. Scherer (Ed.), Keeping good teachers (pp. 153-158). Alexandria, VA: Association for Curriculum and Development.

Gronn P. (2010). Where to next for educational leadership? In T. Bush, L. Bell, and D. Middlewood (Eds.), The Principles of Educational Leadership and Management. London, UK: SAGE.

Guarino, C. M., Santibanez, L., \& Daley, G. A. (2006). Teacher recruitment and retention: A review of the recent empirical literature. Review of Educational Research, 76, 173-208. doi:10.3102/00346543076002173.

Hall, B., Pearson, L., \& Carroll, D. (1992). Teachers' long-range teaching plans: A discriminant analysis. The Journal of Educational Research, 85, 221-225.

doi:10.1080/00220671.1992.9941119 
Hallinger, P., \& Heck, R. (2009), Distributed leadership in schools: Does system policy make a difference? In Harris, A. (Ed.), Distributed Leadership: Different Perspectives. Amsterdam, Netherlands: Springer.

Harris, A. (2011). Distributed leadership: Implications for the role of the principal. Journal of Management Development, 31(1), 7-17.

Harris, A., \& Muijs, D. (2003). Teacher leadership: Principles and practice. London, UK: National College for School Leadership. Retrieved from http://www.nationalcollege.org uk/index./docinfo.htm?id=17417

Hartley, D. (2007). The emergence of distributed leadership in education: Why now? British Journal of Educational Studies, 55(2), 202-214.

Hirsch, E., Emerick, S., Church, K., \& Fuller, E. (2007). Teacher working conditions are student learning conditions: A report on the 2006 North Carolina teacher working conditions survey. Hillsborough, NC: Center for Teaching Quality. Retrieved from http://ncteachingconditions.org/sites/default/files/attachments/twcnc2006.pdf

Horng, E. L. (2009). Teacher tradeoffs: disentangling teachers' preferences for working conditions and student demographics. American Educational Research Journal, 46(3), 690-717.

Hoy, W. K., Tarter, C. J., \& Bliss, J. R. (1990). Organizational climate, school health, and effectiveness: A comparative analysis. Educational Administration Quarterly, 26, 260279.

Hughes, G. D. (2012). Teacher retention: Teacher characteristics, school characteristics, organizational characteristics, and teacher efficacy. The Journal of Educational Research, 105(4), 245-255.

Hulpia, H., Devos, G., \& Van Keer, H. (2009). The influence of distributed leadership on teachers' organizational commitment: A multilevel approach. The Journal of Educational Research, 103, 40-52.

Hulpia, H., Devos, G., \& Van Keer, H. (2010). The influence of distributed leadership on teachers' organizational commitment: A multilevel approach. The Journal of Educational Research, 103, 40-52.

Hulpia, H., Devos, G., Rosseel, Y., \& Vlerick, P. (2012). Dimensions of distributed leadership and the impact on teachers' organizational commitment: A study in secondary education. Journal of Applied Social Psychology, 42(7), 1745-1784. 
Hunting, D., Reilly, T., Whitsett, A., Briggs, S., Garcia, J., \& Hart, B. (May 2017). Finding and keeping educators for arizona's classrooms. ASU Morrison Institute for Public Policy. Retrieved from https://morrisoninstitute.asu.edu/node/196

Ingersoll, R. M. (2001). Teacher turnover and teacher shortages: An organizational analysis. American Education Research Journal, 38, 499-534. doi:10.3102/00028312038003499

Ingersoll, R. M., \& Smith, T. M. (2003). The wrong solution to the teacher shortage. Educational Leadership, 60(8), 30-33.

Johnson, S., \& Birkeland, S. (2003). Pursuing a "sense of success": New teachers explain their career decisions. American Educational Research Journal, 40, 581-617. doi:10.3102/00028312040003581

Karp, S. (2014). Jumping the ship. Catalyst in Depth, 25(3), 4-7.

Kersaint, G., Lewis, J., Potter, R., \& Meisels, G. (2007). Why teachers leave: Factors that influence retention and resignation. Teaching and Teacher Education, 23, 775-794. doi:10.1016/j.tate.2005.12.004

Koh, W. L., Steers, R. M., \& Terborg, J. R. (1995). The effects of transformational leadership on teacher attitudes and student performance in Singapore. Journal of Organizational Behavior, 16, 319-333.

Kukla-Acevedo, S. (2009). Leavers, movers, and stayers: The role of workplace conditions in teacher mobility decisions. The Journal of Educational Research, 102, 443-452. doi:10.3200/JOER.102.6.443-452

Ladd, H. (2009). Teachers' perceptions of their working conditions: How predictive of policyrelevant outcomes. National Center for Analysis of Longitudinal Data in Education Research. (Working Paper No. 33). Washington, DC: CALDER.

Loeb, S., Darling-Hammond, L., \& Luczak, J. (2005). How teaching conditions predict teacher turnover in California schools. Peabody Journal of Education, 80(3), 44-70.

Lumby, J. (2013). Distributed leadership: The uses and abuses of power. Educational Management Administration \& Leadership, 41(5), 581-597.

Moustakas, C. (1994). Phenomenological research methods. Thousand Oaks, CA: SAGE.

Murnane, R. J., Singer, J. D., \& Willett, J. B. (1989). The influences of salaries and "opportunity costs" on teachers' career choices: Evidence from North Carolina. Harvard Educational Review, 59, 325-346.

Nguni, S., Sleegers, P., \& Denessen, E. (2006). Transformational and transactional leadership effects on teachers' job satisfaction, organizational commitment, and organizational 
citizenship behavior in primary schools: The Tanzanian case. School Effectiveness and School Improvement, 17, 145-177.

Prather-Jones, B. (2011). How school administrators influence the retention of teachers of students with emotional and behavioral disorders. The Clearing House, 84, 1-8. doi:10.1080/ 00098655.2010.489387.

Ritchie, R., \& Woods, P. A. (2007). Degrees of distribution: Towards an understanding of variations in the nature of distributed leadership in schools. School Leadership \& Management, 27, 363-381.

Ross, L., Lutfi, G. A., \& Hope, W. C. (2016). Distributed leadership and teachers' affective commitment. National Association of Secondary School Principals Bulletin, 100(3), 159169, SAGE.

Schlichte, J., Yssel, N., \& Merbler, J. (2005). Pathways to burnout: Case studies in teacher isolation and alienation. Preventing School Failure, 50, 35-40.

Skaalvik, E., \& Skaalvik, S. (2010). Teacher self-efficacy and teacher burnout: a study of relations. Teaching and Teacher Education, 26(4), 1059-1069.

Spillane, J. (2006). Distributed Leadership. San Francisco, CA: Jossey-Bass.

Stockard, J., \& Lehman, M. (2004). Influences on the satisfaction and retention of 1st-year teachers: The importance of effective school management. Educational Administration Quarterly, 40, 742-771. doi:10.1177/0013161×04268844

Sulit, A. (2020). Increasing elementary and middle school teacher retention through meaningful distributive leadership practices. Northern Arizona University, ProQuest Dissertations Publishing. 27831418.

Struyven, K., \& Vanthournout, G. (2014). Teachers' exit decisions: An investigation into the reasons why newly qualified teachers fail to enter the teaching profession or why those who do enter do not continue teaching. Teacher and Teacher Education, 43, 37-45.

Sutcher, L., Darling-Hammond, L., \& Carver-Thomas, D. (2016, September). A coming crisis in teaching? Teacher supply, demand, and shortages in the U. S. Learning Policy Institute. (Research Brief). Retrieved from https://learningpolicyinstitute.org/sites/default/files/productfiles/A_Coming_Crisis_in_Teaching_REPORT.pdf

Swars, S. L., Meyers, B., Mays, L. C., \& Lack, B. (2009). A two-dimensional model of teacher retention and mobility: Classroom teachers and their university partners take a closer look at a vexing problem. Journal of Teacher Education, 60, 168-183.

doi: $10.1177 / 0022487108329116$ 
Tahir, L. M., Lee, S. L, Musah, M. B., Jaffri, H., Said, M. N. H. M., \& Yasin, M. H. M. (2016). Challenges in distributed leadership: evidence from the perspective of head teachers. International Journal of Educational Management, 30(6), 848-863.

Thibodeaux, A. K., Labat, M. B., Lee, D. E., \& Labat, C. A. (2015). The effects of leadership and high stakes testing on teacher retention. Academy of Educational Leadership Journal, 19, 227-249.

Timperley, H. S. (2005). Distributed leadership: Developing theory from practice. Journal of Curriculum Studies, 37(4), 395-420.

Torres, D. G. (2017). Distributed leadership and teacher job satisfaction in Singapore. Journal of Educational Administration, 56(1), 127-142.

Tsui, K. T., \& Cheng, Y. C. (1999). School organizational health and teacher commitment: A contingency study with multi-level analysis. Educational Research and Evaluation, 5(3), 249-268.

Van Manen, M. (2014). Phenomenology of practice: Meaning-giving methods in phenomenological research and writing. Walnut Creek, CA: Left Coast Press.

Urick, A. (2016). The influence of typologies of school leaders on teacher retention: A multilevel latent class analysis. Journal of Educational Administration, 54(4), 434-468.

Weiss, E. M. (1999). Perceived workplace conditions and first-year teachers' morale, career choice commitment, and planned retention: A secondary analysis. Teaching and Teacher Education, 15(8), 861-879.

Woods, P. A., \& Woods, G. J. (2013). Deepening distributed leadership: A democratic perspective on power, purpose and the concept of the self. Leadership in Education, 2, $17-40$.

Wynn, S. R., Carboni, L. W., \& Patall, E. A. (2007). Beginning teachers' perceptions of mentoring, climate, and leadership: Promoting retention through a learning communities perspective. Leadership and Policy in Schools, 6, 209-229.

doi:10.1080/15700760701263790 